\title{
Exploring new inflammatory pathways in the synovium
}

\author{
I B Mclnnes \\ From 5th European Workshop on Immune-Mediated Inflammatory Diseases \\ Sitges-Barcelona, Spain. 1-3 December 2010
}

Immune mediated pathways are now recognized to play a significant role in many common pathologies. The immune system comprises a complex series of interactions between cellular and molecular networks. The complexity arises mainly from the requirement to offer host defence against an almost infinite microbial pathogenic attach, together with a requirement to regulate matters such that host tissue damage is uncommon or at least limited. Failure of these complex regulatory pathways often leads to induction or amplification of pathology. Using rheumatoid arthritis as an exemplar, this lecture will consider the opportunities available for clinical intervention now arising as the molecular regulatory pathways in immune responses are unraveled. The clinical success of biologic agents that target cytokines e.g. tumour necrosis factor and interleukin- 6 receptor provide definitive proof of concept that there are tractable checkpoints in the immune network. In future, as more information emerges as to how the immune system is organized in health and disease, it will become possible to intervene with greater discretion eventually to allow the re establishment of immune homeostasis - that is the creation of immune tolerance. Such approaches offer the prospects for inflammatory disease anticipation, abrogation and even prevention. The potential for cellular modulatory pathways will be explored in novel models of breach of tolerance. Similarly

Institute of Infection, Immunity and Inflammation, College of Medical, Veterinary and Life Sciences, University of Glasgow, UK new approaches to molecular complexity in the synovium in particularly concerning microRNAs will be described.

Published: 25 November 2010

doi:10.1186/1479-5876-8-S1-I10

Cite this article as: Mclnnes: Exploring new inflammatory pathways in the synovium. Journal of Translational Medicine 2010 8(Suppl 1):110.

Submit your next manuscript to BioMed Central and take full advantage of:

- Convenient online submission

- Thorough peer review

- No space constraints or color figure charges

- Immediate publication on acceptance

- Inclusion in PubMed, CAS, Scopus and Google Scholar

- Research which is freely available for redistribution 